\title{
RESEARCH OF STRUCTURE AND PROPERTIES OF BIOTECHNOLOGICAL COLLAGEN-CONTAINING PREPARATION
}

\author{
O. Andreyeva, L. Maistrenko, A. Nikonova \\ Kyiv National University of Technologies and Design
}

\begin{tabular}{l}
$\quad$ Key words: \\
Biotechnological \\
preparation \\
Collagen containing \\
wastes \\
Chemical analysis \\
microbiological and \\
IR-spectroscopic \\
researches \\
\hline
\end{tabular}

Article history:

Received 03.09.2018

Received in revised form

19.09.2018

Accepted 17.10.2018

Corresponding author:

O. Andreyeva

E-mail:

npnuht@ukr.net

\begin{abstract}
Leather industry is one of the main producers of collagen-containing raw materials. Therefore, effective recycling of these raw materials into marketable products is a pressing problem not only for leather industry but also for other fields of human activity and environmental ecology. Among the most important areas of using collagen-containing materials, it is possible to product the additives and emulsions containing of protein and fat component; the production of multifunctional drugs and structured products (type of extrudate and crisps); gelatine manufacturing; production of preparations for fragrance and cosmetics industries, veterinary medicine, medicine, leather manufacturing etc.

It has been investigated a new Ukrainian collagen-containing preparation, obtained by biotechnology, from nontanned leather wastes (raw material from bovine hides in the form of macromolecular-purified fibrous product). Since the content of toxic elements in the preparation is less than the maximal acceptable level, and microbiological studies indicate the absence of pathogenic microflora it can be ascribed to non-toxic, environmentally friendly products.

The size of particles in collagen preparation was assessed using microscopy. Chemical analysis identified chemical composition (moisture content, as well as protein, fats and minerals content). The presence of different functional groups in the structure of investigated preparation was detected by IR-spectroscopy. Based on the results of experimental data it is assumed the possibility of practical use of this new collagen-containing preparation as secondary raw materials in many sectors of national economy.
\end{abstract}

DOI: $10.24263 / 2225-2924-2018-24-5-7$ 


\title{
ДОСЛІДЖЕННЯ СТРУКТУРИ ТА ВЛАСТИВОСТЕЙ БІОТЕХНОЛОГІЧНОГО КОЛАГЕНВМІСНОГО ПPEחAPATATY
}

\author{
О.А. Андреєва, Л.А. Майстренко, А.В. Ніконова \\ Київський національний університет технологій та дизайну
}

Шкіряне виробництво є одним із потужних джерел утворення значних ресурсів колагенвмісних матеріалів, ефективна переробка яких $і$ подальше використання одержаних продуктів мають величезне значення для різних сфер діяльності людини та екологї навколишнього середовища. Серед актуальних напрямів використання колагенвмісних матеріалів можна виділити одержання протеїново-жирових добавок та емульсій, желатину, структурованих продуктів (типу екструдату, чипсів), багатофункціональних препаратів для харчової, парфумерно-косметичної та легкої промисловості, медицини, ветеринарії, зоотехнії тошзо.

Досліджено новий вітчизняний колагенвмісний препарат, одержаний біотехнологічним шляхом з недублених відходів шкіряного виробництва (вихідна сировина - икури великої рогатої худоби у вигляді високомолекулярного очищеного волокнистого продукту). Оскільки вміст токсичних елементів у препараті менший за гранично допустимий рівень, а мікробіологічні дослідження вказують на відсутність патогенної мікрофлори, його можна віднести до нетоксичних та екологічно чистих продуктів.

За допомогою мікроскопічного методу дослідження встановлено розмір частинок изього препарату, хімічного аналізу - його хімічний склад (вміст вологи, а також білкових, жирових і мінеральних речовин), ГЧ-спектроскопїнаявність у структурі функиіональних груп різної природи. На підставі одержаної інформачії зроблено припущення щзодо можливості практичного використання цьвого препарату як вторинного сировинного ресурсу в різних сферах господарювання.

Ключові слова: біотехнологічний препарат, колагенвмісні відходи виробництвва, хімічний аналіз, мікроскопічні та ІЧ-спектроскопічні дослідження.

Постановка проблеми. Головною складовою сполучної тканини шкірного покриву тварин є колаген [1; 2]. Оскільки шкури тварин протягом тисячоліть продовжують залишатися єдиним матеріалом для виготовлення желатину, виробів 3 натуральних шкіри і хутра, випливає величезне технічне значення колагену та нагальна потреба у колагенвмісних сировинних ресурсах.

Під час виготовлення шкіри, а потім взуття чи одягу, тобто в ланцюжку «шкура-шкіра-виріб 3 натуральної шкіри» у відходи переходить близько 40\% колагенвмісної сировини [3], а за даними [4] — майже 50\%. Отже, рішення проблеми перероблення та використання колагенвмісних матеріалів є важливим науково-практичним завданням, вирішення якого можли- 
ву або шляхом створення безвідходних технологій перероблення колагенвмісної сировини, або переведення останньої в однорідний стан для подальшого використання.

Дослідження такої багатокомпонентної та багатофункціональної системи, як сполучна тканина стало можливим завдяки розробці науково обгрунтованих методів виділення нативного колагену зі сполучної тканини, що дало змогу зберегти молекулярну структуру та біологічну активність цього білка при максимальному рівні очищення від супутніх речовин. При цьому колагенвмісні продукти одержують як у твердому, так і в розчиненому стані [5; 6]. Все це значно розширює можливості застосування колагенвмісних відходів. Так, наприклад, голинну спилкову обрізь шкур великої рогатої худоби, як один 3 основних видів білоквмісних відходів, переробні підприємства нині активно використовують як сировину для отримання розчинних форм колагену, які застосовуються у ветеринарії, медицині, косметології та харчовій промисловості, що уможливлює створення ряду принципово нових препаратів і біоматеріалів. 3 викладеного випливає, що колагенвмісні відходи є цінними як сировина для переробних підприємств, тобто набули споживчої вартості та статусу промислового товару. Те саме можна сказати і про розчинні форми колагену, одержувані із зазначених відходів. Такого роду товари, незважаючи на поки що високу вартість, користуються великим попитом, хоча асортимент їх невеликий, а до якості висуваються досить жорсткі вимоги.

Одним із потужних джерел утворення значних ресурсів колагенвмісних матеріалів є шкіряне виробництво [8-9]. Аналіз літературних джерел [3; 7; 10] показав, що в наш час склалися різні напрями їх використання, наприклад, виробництво протеїново-жирових добавок та емульсій, желатину, структурованих продуктів і багатофункціональних препаратів для харчової, парфумерно-косметичної та легкої промисловості, ветеринарії, зоотехнії, медицини тощо.

3 урахуванням викладеного проведено всебічні дослідження нового біотехнологічного препарату, одержаного 3 недублених колагенвмісних матеріалів шкіряного виробництва торговельної марки «Геліос-11» (Україна) [11; 12], який являє собою натуральний високомолекулярний очищений волокнистий білок, отриманий зі шкур ВРХ за спеціальною біотехнологічною схемою.

Вміст токсичних елементів у препараті менший за гранично допустимий рівень (табл. 1), у ньому відсутня патогенна мікрофлора (табл. 2), тому його можна віднести до нетоксичних екологічно чистих продуктів.

Табличя 1. Вміст токсичних елементів у препараті [12]

\begin{tabular}{|c|c|c|}
\hline \multirow{2}{*}{ Елемент } & \multicolumn{2}{|c|}{ Вміст, мг/кг } \\
\cline { 2 - 3 } & Препарат & $\begin{array}{c}\text { Нормативна } \\
\text { документація }\end{array}$ \\
\hline Свинець & 0,092 & не $>1,0$ \\
\hline Кадмій & 0,013 & не $>0,1$ \\
\hline Арсен & 0,309 & не $>1,0$ \\
\hline Ртуть & $<0,01$ & не $>0,03$ \\
\hline Мідь & 1,24 & не $>30,0$ \\
\hline
\end{tabular}


Табличя 2. Мікробіологічні показники препарату [12]

\begin{tabular}{|c|c|c|}
\hline Показник & Препарат & $\begin{array}{c}\text { Нормативна } \\
\text { документація }\end{array}$ \\
\hline $\begin{array}{c}\text { Кількість мезофільних аеробних і факультативно } \\
\text { анаеробних мікроорганізмів, КУО в 1 г }\end{array}$ & $3,2 \cdot 10^{3}$ & не $>5 \cdot 10^{4}$ \\
\hline БГКП (коліформні мікроорганізми), в 1 г & не виділено & не допускається \\
\hline Патогенні мікроорганізми, у тому числі Salmonella, в 25 г & не виділено & не допускається \\
\hline Licteria топосуtogenus, в 25 г & не виділено & не допускається \\
\hline СРК (сульфітредукуючі клостридії), в 1 г & не виділено & не $>5 \cdot 10^{1}$ \\
\hline Staphylococcus aureus, в 1 г & не виділено & не допускається \\
\hline
\end{tabular}

Метою статті $\epsilon$ дослідження вітчизняного препарату колагену, виявлення можливості його практичного використання у різних сферах господарювання.

Викладення основних результатів дослідження. Використано український білковий препарат, одержаний 3 недублених колагенвмісних матеріалів шкіряного виробництва від шкур великої рогатої худоби (далі - препарат). Оцінювання властивостей препарату виконували відповідно до вимог [13; 14]. Середню пробу препарату для випробувань відбирали після перемішування в упаковці. Для одержання достовірних результатів усі необхідні вимірювання та визначення проводили не менш, ніж у трьох дослідах, а під час проведення об'ємних аналізів виконували контрольні досліди, вносячи до розрахунків відповідні поправки.

Під час експерименту використали різноманітні методи дослідження: мікроскопічний - для визначення розміру частинок колагенвмісного препарату (мікроскоп Bresser Researcher Bino (Bresser, Німеччина), ІЧ-спектроскопічний для ідентифікації його активних груп (спектрофотометр TENSOR 37, Brucer, Німеччина), математичну статистику та деякі інші [15].

За показники дослідження обрали такі, що найбільшою мірою описують фізико-хімічні властивості досліджуваного препарату: розмір частинок, масову частку вологи, голинної речовини, жиру та мінеральних речовин (золи) тощо.

Візуально досліджуваний препарат має вигляд однорідного, світлого дрібно волокнистого продукту без запаху. Завдяки мікроскопічним дослідженням встановлено розміри частинок препарату. Дані табл. 3 свідчать про високу рівномірність та однорідність цього показника $(E<5 \%)$. Основною складовою досліджуваного препарату є голинна речовина (тобто колаген), вміст якої становить понад 90\%. Вміст мінеральних і жирових речовин набагато менший - 3,9 та 1,0\% відповідно.

Таблиия 3. Показники досліджуваного препарату

\begin{tabular}{|c|c|}
\hline Показник & Значення \\
\hline Розмір частинок, мм*: & \\
- поздовжній & $0,139 \pm 0,001$ \\
- поперечний & $0,138 \pm 0,001$ \\
\hline Масова частка, \%: \\
- голинна речовина* & $90,1 \pm 0,3$ \\
- мінеральні речовини* & $3,9 \pm 0,4$ \\
\hline - речовини, що екстрагуються органічними розчинниками* & $1,0 \pm 0,8$ \\
\hline
\end{tabular}

Примітка. * 13 паралельних дослідів; ** у перерахунку на абсолютно суху речовину (три паралельних досліди). 


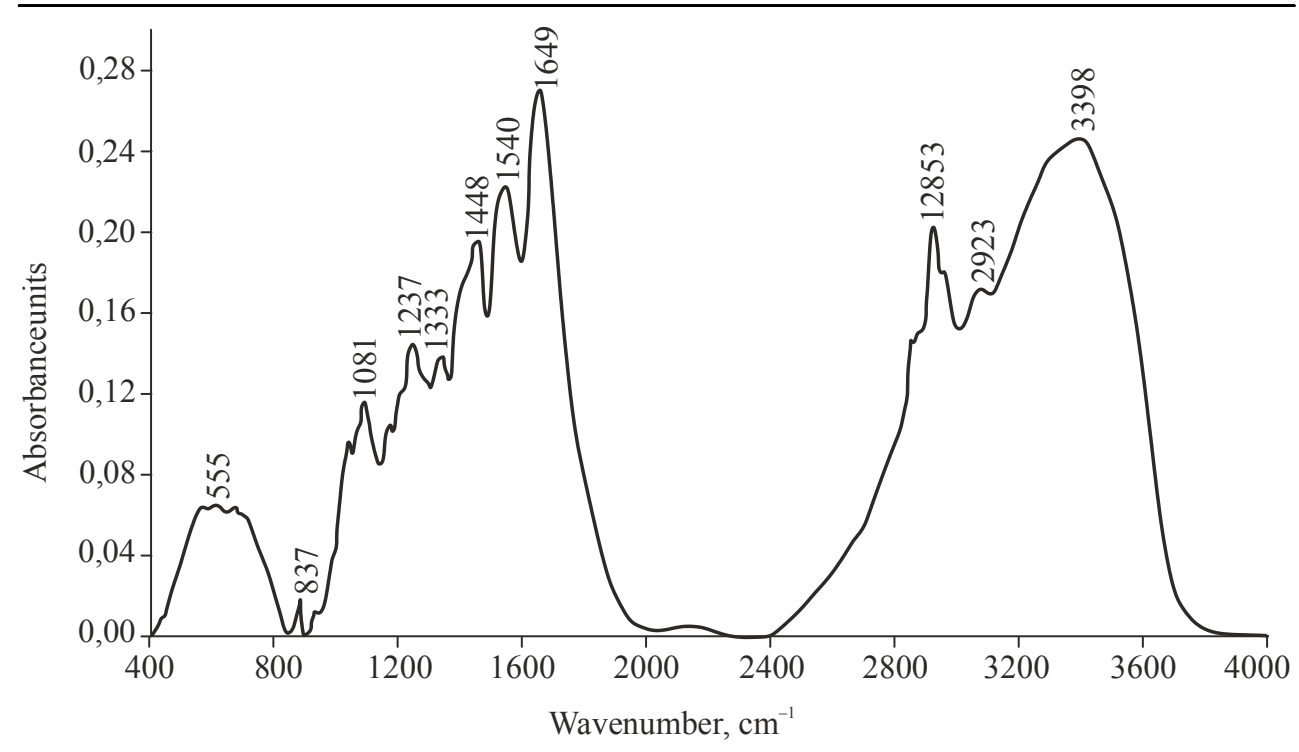

Рисунок. ІЧ-спектрограма препарату колагену

Для встановлення структурних особливостей препарату використали метод інфрачервоної спектроскопії. На спектрограмі препарату (рис.) найбільш чітко виділяються смуги при частотах 3398, 1649, 1540, 1237 та $555 \mathrm{~cm}^{-1}$, яким відповідають коливання амінів, карбонових кислот та амідів А, I, II, III, VI 3 різною часткою складових, а також при частоті $1448 \mathrm{~cm}^{-1}$, якій відповідають деформаційні коливання ОН-груп.

Має місце широка смуга при частоті 2500-3800 $\mathrm{cm}^{-1}$, що відповідає валентним коливанням ОН-груп карбонових кислот. Наявність зазначених груп пояснюється тим, що препарат $\epsilon$ похідною колагену і під час свого виготовлення зазнав гідролітичного впливу лужних та інших реагентів.

Виявлена наявність у структурі досліджуваного препарату колагену низки функціональних груп (насамперед амідних - до їх складу входять $\mathrm{NH}, \mathrm{C}=\mathrm{O}$, $\mathrm{CN}$, а також аміно-, карбоксильних і гідроксильних). Це вказує на поліфункціональну природу цього матеріалу та його здатність взаємодіяти з різними хімічними матеріалами.

На підставі одержаної інформації зроблено припущення щодо використання досліджуваного препарату як вторинного сировинного ресурсу в різних сферах господарювання завдяки збереженню його волокнистої структури $\mathrm{i}$ таким цінним його властивостям, як нетоксичність, екологічність, поліфункціональність, спорідненість до колагену.

\section{Висновки}

Проаналізовано властивості вітчизняного біотехнологічного препарату, одержаного з недублених відходів шкіряного виробництва. 3 використанням хімічного та сучасних інструментальних методів аналізу визначено його основні фізико-хімічні показники та структурні особливості. Встановлено, що досліджуваний препарат утворений 3 дрібних волоконець, містить багато 
білкових речовин, але мало жирових та мінеральних і, головне, має поліфункціональну природу завдяки наявності цілої низки функціональних груп: амідних, амінних, карбоксильних, гідроксильних. На підставі одержаної інформації зроблено припущення щодо практичного використання досліджуваного препарату як вторинного сировинного ресурсу у різних сферах господарювання.

\section{Література}

1. Михайлов А.Н. Коллаген кожного покрова и основы его переработки. Москва: Легк. индустрия, 1971. 527 с.

2. Журавський В.А., Касьян Е.Є., Данилкович А.Г. Технологія шкіри та хутра: підручник. Київ: [ДАЛПУ], 1996. 743 с.

3. Пустыльник Я.И. Кожевенные отходы - золотое дно. В мире оборудования. 2002. № 2(19). С. $44-48$.

4. Журавский В.А. Малоотходная технология кожевенного производства. Москва: Легпромбытиздат, 1993. $125 \mathrm{c}$.

5. Карпухина Л.И., Пономарёва А.В., Чайковский Р.И. Переработка отходов кожевенно-обувного производства: справочник. Киев: Техника, 1983. 85, [1] с.

6. Белевцова Д. В. Оценка качества коллагенсодержащих отходов и получаемых на их основе золей коллагена: дис. ... канд. техн. наук: 05.19.08. Товароведение промышленных товаров и сырья легкой пром-сти / Моск. гос. акад. ветерин. медицины и биотехнологии им. К.И. Скрябина. Москва, 2006. 141 с.

7. Biopolymers systems from leather wastes for degraded soils remediation./ G.A. Zainescu, M. Mihalache, P. Voicu, R. Constantinescu, L. Ilie, M. Obrisca. Scientific Papers, UASVM Bucharest. 2011. LIV. P. 60-68.

8. Yang H., Shu Z. The extraction of collagen protein from pigskin. J Chem Pharm Res. 2014. 6(2). P. 683-687.

9. Brown E.M., Taylor M.M., Marner W.N. Production and potential uses of co-products from solid tannery waste. J Am Leather Chem Assoc. 1996. 91. P. 270-275.

10. Casparus J. Products and application of biopolymers. Croatia: InTeh, 2012. 220 p.

11. Andreyeva O.A., Maistrenko L.A., Tegza M.M. The usage of materials polyfunctionality in modern low-waste technologies. Materials of the III International research and practice conference «International Conference on European Science and Technology». Munich: Publishing office Vela Velard Waldkraiburg : 2012. Vol. I. P. 107-111.

12. Тегза М.М., Андреєва О.А. Дослідження препаратів колагену. Вісник ХНУ. 2011. № 4. С. $128-132$.

13. Данилкович А.Г., Чурсин В.И. Практикум по химии и технологии кожи и меха: Учебное пособие. Москва: ЦНИИКП, 2000. 413 с.

14. Жебентяев А.И. Жерносек А.К.,. Талуть И.Е Аналитическая химия. Химические методы анализа : учеб. пособие. Минск: Новое знание, 2010. 542 с.

15. Васильев А.В. Гриненко Е.В., Щукин А.О., Федулина Т.Г. Инфракрасная спектроскопия органических и природных соединений: учеб. пособие. Санкт-Петербург: СПбГЛТА, 2007. $54 \mathrm{c}$. 